\title{
Techno-Economic Analysis of Electrical Energy Generation from Urban Waste in Hamadan, Iran
}

\author{
Reza Alayi $i^{*}$, Hamed Rouhi $^{2}$ \\ ${ }^{1}$ Department of Mechanics, Germi Branch, Islamic Azad University, Germi 5651763764, Iran \\ ${ }^{2}$ Department of Energy Engineering, Energy Institute of Higher Education, Saveh 3917767746, Iran
}

Corresponding Author Email: reza_alayi@iaugermi.ac.ir

https://doi.org/10.18280/ijdne.150307

Received: 15 February 2020

Accepted: 21 April 2020

\section{Keywords:}

energy analysis, biomass, urban waste, electricity

\begin{abstract}
Due to the growing population of urban waste production and pollution has increased On the other hand, have also been considered due to the excessive consumption of fossil fuels, environmental issues. In addition, in crowded cities, the production of urban waste is due a major risk for environmental issues. Proper use of municipal waste can reduce pollution and provide some of the energy load. In this research, chemical analysis of urban waste related to Hamedan has been done, estimated the heating value of urban waste incineration. In this way, the approximate amount of energy obtained can be obtained before designing the system. After estimating the heating value of urban waste from the constituent materials, was designed the biomass power plant, then were obtained the amounts of electricity generated by biomass power plants, as well as the amount of investment and income from the sale of electricity. One of the most important results is the maximum electrical energy production of $3559.08 \mathrm{MW} /$ month, that's for this month the income of selling is $320317 \$$.
\end{abstract}

\section{INTRODUCTION}

Reasons for using renewable energy include: reducing fossil fuels, diversification of energy resources, sustainable development and energy security, environmental problems caused by the use of fossil fuels [1-4]. The increased in the share of these resources in the global energy portfolio. The development and expansion of the use of renewable energy achieve the goals of economic, social, and environmental development of societies.

In a way, the use of renewable energy can reduce dependence on fossil resources and reduce the emission of polluting gases and greenhouse gases that have a major impact on global warming. Among these, biomass (biomass) can be mentioned as an important and interesting renewable energy source that can be used with little preparation [5-9].

On the other hand, industrial growth has been an important factor in increasing per capita income and people's welfare, and as a result, more waste has been produced. As the degree of economic development increases, so does the per capita output. Because, with increasing income, the level of consumption increases, the amount of goods purchased, and as a result, the production of waste also increases [10-13].

As a result, within a metropolis, the rate of waste generation may vary greatly from region to region. In general, it can be said that the head of waste production in high-income areas is higher than low-income or medium-income areas.

Energy production from municipal waste incinerators is the most attractive category in terms of technical, economic, environmental, and social among other methods of urban waste disposal [14-17].

At present, the world is paying close attention to the issue of energy production from urban waste, and Europe's electricity generation capacity from this source has more than doubled in the past few years [18]. Several studies have also reported the use of electrical generation with urban waste such as Santos et al. [19], Araujo et al. [20], Isnam et al. [21], Sjöblom et al. [22]. Many studies have also reported the economic and environmental analysis in electrical generation with urban waste such as Ayodele et al. [23], Fernández et al. [24], Singh et al. [25], Owebor et al. [26].

There are more studies in electrical generation with urban waste. Saldaña-Durán et al. [27] have provided a research titled Environmental pollution of E-waste: generation, collection, legislation, and recycling practices in Mexico. Zhang et al. [28] have provided a research titled Distributed Renewable Energy in China: Current State and Future Outlook. Cudjoe et al. [29] have provided a research titled Electricity generation using biogas from organic fraction of municipal solid waste generated in provinces of China: Technoeconomic and environmental impact analysis.

In this study, by separating the waste of Hamadan city, the thermal value of the fuel obtained in the laboratory has been obtained and by analyzing the combustion process of the obtained fuel, the potential measurement for the construction of the waste incineration plant has been done.

\section{MATRIAL AND METHOD}

\subsection{Area study}

The urban waste collection site is southwest of Hamadan city. Due to the fact that this site is a reception center for solid waste in different parts of the region. The amount of solid waste transferred is much higher than the waste produced in 
the city of Hamadan, so that considering the population of Hamedan and the surrounding towns and villages, the waste of nearly two million and five hundred thousand people of this region will be buried in the traditional landfill of Hamadan.

The various parts of the current waste management system implemented in this city include segregation of origin, storage of waste collection on the production site, transportation of waste in and out of the city, recycling and other waste conversion industries and finally landfilling in the landfill of each. It runs with different qualities and methods.

According to the available information, the amount of waste entering the landfill of this city is 1300 tons of waste per day, which after the pre-processing operation, about 40 tons of this waste will be separated and re-separated.

According to the population located in the waste management basin in the region, each person produces an average of $765 \mathrm{gr} /$ day of industrial, urban and hospital waste.

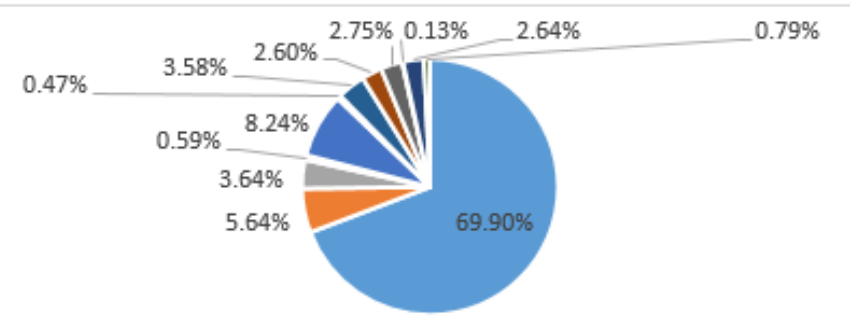

$\begin{array}{lll}\text { - Corruptible } & \text { " Paper } & \text { " Cardboard } \\ \text { = Tires } & \text { - Plastic } & \text { | Pet } \\ \text { - Cloth } & \text { - Glass } & \text { - Iron metals }\end{array}$

- Non-ferrous metals a Construction debris . Wood

-

Figure 1. Compounds of waste components of Hamadan city per year [source: wm. hamedan.ir]

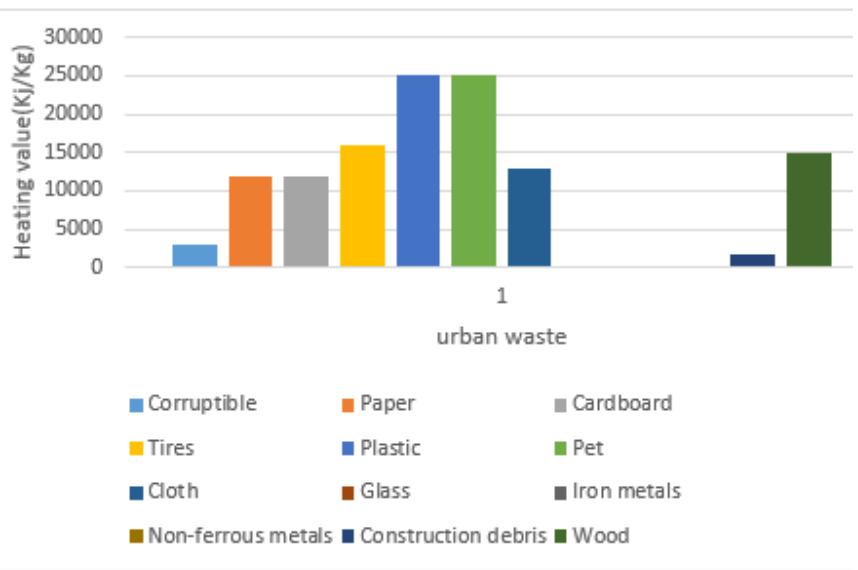

Figure 2. Heating value of urban waste components

Table 1. Information on urbane waste [source: wm. hamedan.ir]

\begin{tabular}{ccc}
\hline Type & Amount & Unit \\
\hline Ability to produce gas from each kilogram of & 350 & Liter \\
TS removed & & \\
Digestive efficiency in removing TS & 55 & $\%$ \\
Percentage of total solids & 17 & $\%$ \\
Total amount of corruption & 898 & Ton \\
\hline
\end{tabular}

Based on the results of studies and information obtained, the amount of waste compounds collected and heating value for urban waste in this city is in accordance with Figure 1 and Figure 2 and other information related to the amount of waste is in accordance with Table 1. As can be seen, the percentage of the perishable sector is high, which indicates the potential for energy extraction.

\subsection{Biomass power plant design}

After transferring the waste collected from the city to the power plant, these materials are divided into two categories: contaminated and non-contaminated.

All contaminated waste is sent directly to the heating unit, and the other category is divided into two parts, perishable and non-perishable, after passing through the separation route. Corruptible components, then enter the anaerobic digestion system for energy production by anaerobic units after being crushed and controlled.

The gas produced in these units, after collecting the purification processes, is transferred to the unit of storage and production of electrical energy. The engine of the plant's biogas gas generators is responsible for generating energy from the biogas produced.

The heat generated during the power generation process can be consumed in local units that require heat. Some of the excess heat produced will also be used to heat the digestive tanks. After passing through the additional stages, the nonperishable part is separated from the consumable components and transferred to the gasification unit with the remaining components to be converted into artificial gas under thermal processes.

After purification, the resulting gas is consumed in electricity generation systems and the generated electricity is injected into the national electricity grid.

\subsection{Biomass power plant}

Calculation of electric power plant of the thermal unit (gasification) based on the following procedure can be done. The amount of potential energy that can be generated from waste is obtained from Eq. (1):

$$
P=N C V * W *\left(\frac{1000}{860}\right)=162 \times N C V \times W
$$

In Eq. (1), $\mathrm{P}$ is the net energy potential $(\mathrm{kWh}), \mathrm{W}$ is the amount of waste (tons) and NCV is the net calorific value $(\mathrm{Kcal} / \mathrm{kg})$. Based on this, the amount of electric power that can be produced in terms of (Kw) in Eq. (2) is presented.

$$
P=1.162 \times W \times(W / 24)=0.048 \times N C V \times W
$$

According to the above, the practical potential of generating electrical energy from waste can be presented as the following Eq. (3).

$$
P(M W)=\left(\sum(R \times C V) \times 1.1157 \times 10^{-5}\right)
$$

P: Practical potential for waste energy generation by waste incineration, R: Production rate corruptible waste containing energy (tons/day), $\mathrm{CV}$ : of heating value $(\mathrm{Kj} / \mathrm{K})$ and $1.157^{*} 10^{-}$ 5 : constant number. 


\subsection{Economic analysis}

In order to evaluate the design economically, the basis of the comparison is the production of steam with a bar pressure of $10 \mathrm{bar}$ and a temperature of $500 \mathrm{0F}$. And the fixed and current costs of incinerators and heat recovery boilers have been compared with a useful life of 20 years with a burner boiler with a useful life of 15 years.

The annual operating time of the recovery boiler is 75,000 hours and the installation cost are about $12 \%$ of the equipment price. The fuel used for boilers is considered to be a diesel. The following equation 4 can be used to estimate the current value of costs over $n$ years, with interest rate $i$ and adjustment rate $\mathrm{e}$. The annual maintenance cost is $5 \%$ of the final installation cost.

$$
\begin{gathered}
Z_{k}=T C I * C R F \\
T C I=6.32 * C_{B} \\
C R F=\frac{i(1+i)^{N}}{(1+i)^{N}-1}
\end{gathered}
$$

\section{RESULT}

Waste analysis shows that this waste has the following chemical formula:

$$
\mathrm{CH}_{1.626} \mathrm{~N}_{0.03766} \mathrm{~S}_{0.0025} \mathrm{Cl}_{0.010} \mathrm{O}_{0.645}+2.702 \mathrm{H}_{2} \mathrm{O}
$$

One of the prominent negative characteristics of waste is its high humidity of about $60 \%$, which reduces its heating value. The average lower heating value of Hamedan waste with moisture according to the experiment is equal to $5382 \mathrm{kj} / \mathrm{kg}$. This heating value is equivalent to $6510 \mathrm{kj} / \mathrm{kg}$ High Heating Value (HHV), according to the World Bank's report on the minimum low heating value required for the construction of a waste incinerator $(7 \mathrm{kj} / \mathrm{kg})$, waste disposal should reach the desired level of heating value.

Expanding the separation of wet and dry waste can also significantly help increase heating value. Table 2 can be presented by considering different percentages of waste moisture.

As can be seen in Table 2, by reducing the moisture content of the waste, the desired thermal value can be achieved for the operation of the incinerator.

Table 2. Higher heating value of waste according to the percentage of waste moisture

\begin{tabular}{cc}
\hline $\begin{array}{c}\text { Weight percentage of waste } \\
\text { moisture }\end{array}$ & $\begin{array}{c}\text { High heating value } \\
(\mathbf{K j} / \mathbf{K g})\end{array}$ \\
\hline $0 \%$ & 1625 \\
$30 \%$ & 11375 \\
$60 \%$ & 65 \\
\hline
\end{tabular}

Figure 3 shows the amount of electricity generated by urban waste and Figure 4 shows Electric energy generated by biomass power plant for Hamedan City.

According to Figure 3, the highest production of electrical energy is related to plastics, this is because plastic is very high heating value, that's about $25,000(\mathrm{Kj} / \mathrm{Kg})$. Plastic alone can produce $29.8 \mathrm{MW} /$ day. urban waste such as glass, Iron metals and Non-ferrous metals reduces the heating value.

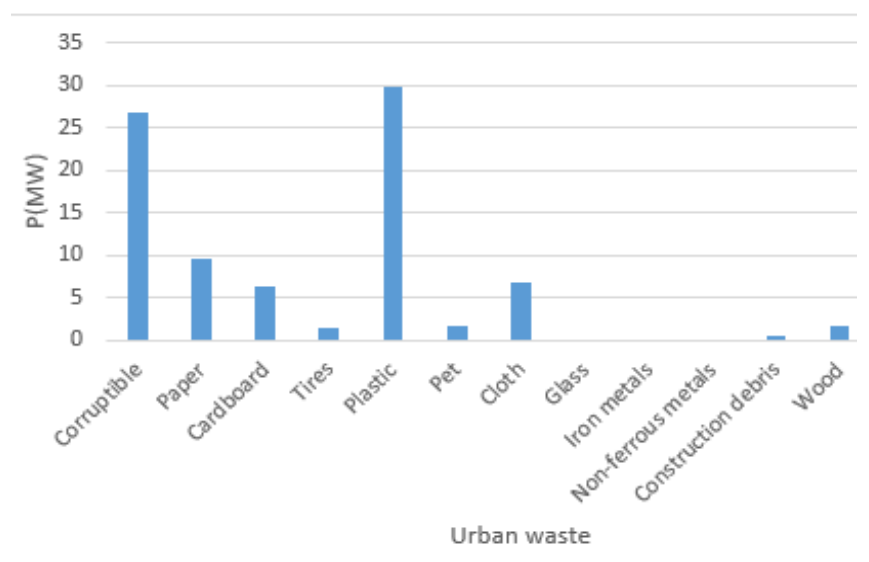

Figure 3. Electric energy generated by various urban wastes

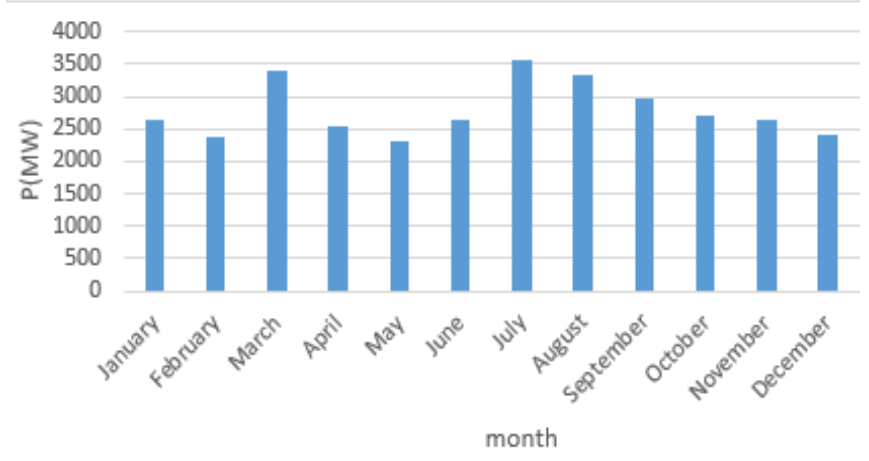

Figure 4. Electric energy generated by biomass power plant for Hamadan City

According to Figure 4, the highest and lowest production of electrical energy from biomass power plant is related to July and May. The electricity energy produced in the month of July is equal to $3559.08 \mathrm{MW}$, while this amount for the month of May is equal to $2300 \mathrm{MW}$.

To calculate the economic benefits of biomass, the amount of methane gas obtained from the combustion of biomass resources can be considered in the environmental and social costs resulting from the estimate of the electricity production equivalent to the potential of the region.

Due to the fact that the exhaust output of the waste incineration system is the gases from the combustion of biomass materials, the main one of which is carbon dioxide gas.

Therefore, in order to consider the economic benefits obtained from the construction of this system, based on the studies done, the average external costs of carbon dioxide gas produced in a similar power plant that is borne by the society are equal to $0.03 \$ / \mathrm{kWh}$ of production.

Therefore, as a result of the construction of this power plant, the value of the social benefits resulting from the nonconstruction of a power plant similar to fossil fuels is equal to: The amount of electrical energy that ability be produced in the power plant equal 7.74 Mwe, that amount Energy produced per year equal 58050 Mwhe. Based on this, and considering two different modes for investor rate, inflation and price growth rate, the results of economic comparison are presented in Table 3.

In Figure 5, can be seen the amount of income from bio mass power plant. This income comes from the sale of electricity to the grid or other consumers. The rate of 
electricity sales is $0.09 \$ / \mathrm{kwh}$, which has been obtained for clearer analysis compared to different months.

As shown in Figure 5, The highest income is for July with $320317 \$$ and the lowest income from the sale of electricity generated in May is 207000\$.

The total income from the sale of electricity generated from the biomass power plant in the Hamedan city, according to the amount of urban waste, is equal to $3.882 \mathrm{M} \$$ /year.

Table 3. Economic comparison of incinerator and burner boiler for production of 100 tons of gas and 50 degrees Super

\begin{tabular}{cccc}
\hline Description & $\begin{array}{c}\text { Initial } \\
\text { investment }\end{array}$ & $\begin{array}{c}\text { Fuel } \\
\text { cost }\end{array}$ & $\begin{array}{c}\text { Total } \\
\text { costs }\end{array}$ \\
\hline Waste incineration & $0.22 \mathrm{M} \$$ & $2.19 \mathrm{M} \$$ & $2.41 \mathrm{M} \$$ \\
Boiler with torch & $4.44 \mathrm{M} \$$ & $0.7 \mathrm{M} \$$ & $4.51 \mathrm{M} \$$ \\
\hline
\end{tabular}

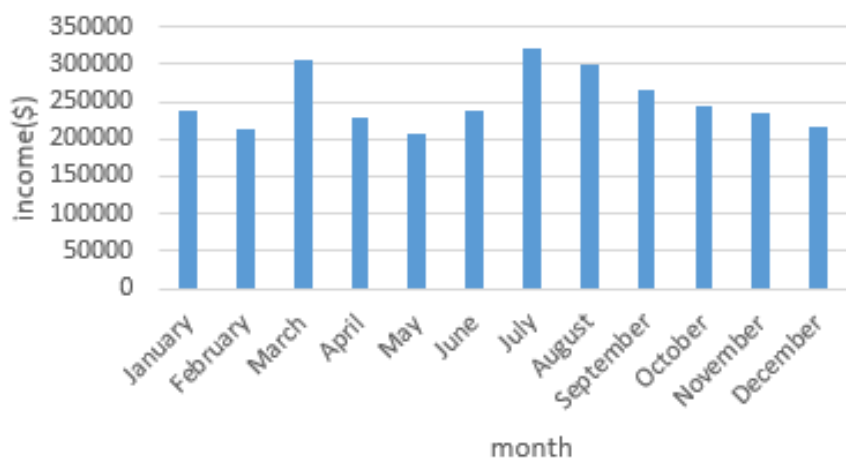

Figure 5. Income from the sale of electricity from the biomass power plant

\section{CONCLUSIONS}

A waste incineration plant is a definitive solution for the sanitary disposal of waste, for areas that do not have enough land for landfilling.

After studies and studies, urban waste has a relatively low heating value for energy production, and this is due to the high moisture content of food waste. If there is a design to recover energy, it is better to burn the waste or to separate or preheat the waste to reduce its moisture.

The use of auxiliary combustion in the incinerator depends on the dimensions of the design. According to Table 3, the initial investment of an incinerator requires a higher cost than a burner boiler, but with the price growth rate for fuel and no cost for waste, as well as the elimination of the problem of waste disposal and health problems.

\section{REFERENCES}

[1] Alayi, R., Kasaeian, A., Atabi, F. (2019). Thermal analysis of parabolic trough concentration photovoltaic/thermal system for using in buildings. Environmental Progress \& Sustainable Energy, 38(6): 13220. https://doi.org/10.1002/ep.13220

[2] Holden, E., Linnerud, K., Banister, D. (2017). The imperatives of sustainable development. Sustainable Development, 25(3): 213-226. https://doi.org/10.1002/sd.1647

[3] Alayi, R., Shamel, A., Kasaeian, A., Harasii, H., Topchlar, M.A. (2016). The role of biogas to sustainable development (aspects environmental, security and economic). Journal of Chemical and Pharmaceutical Research, 8(4): 112-118.

[4] Alayi, R., Sobhani, E., Najafi, A. (2020). Analysis of environmental impacts on the characteristics of gas released from Biomass. Anthropogenic Pollution Journal, 4(1):

$1-14$. https://doi.org/10.22034/ap.2020.1879800.1052

[5] Alayi, R., Kasaeian, A., Najafi, A., Jamali, E. (2019). Optimization and evaluation of a wind, solar and fuel cell hybrid system in supplying electricity to a remote district in national grid. International Journal of Energy Sector Management, 14(2): 408-418. https://doi.org/10.1108/IJESM-04-2019-0019

[6] Umar, M.S., Urmee, T., Jennings, P. (2018). A policy framework and industry roadmap model for sustainable oil palm biomass electricity generation in Malaysia. Renewable Energy, 128: 275-284. https://doi.org/10.1016/j.renene.2017.12.060

[7] Roni, M.S., Chowdhury, S., Mamun, S., Marufuzzaman, M., Lein, W., Johnson, S. (2017). Biomass co-firing technology with policies, challenges, and opportunities: A global review. Renewable and Sustainable Energy Reviews, 78: 1089-1101. https://doi.org/10.1016/j.rser.2017.05.023

[8] Wang, M., Dewil, R., Maniatis, K., Wheeldon, J., Tan, T., Baeyens, J., Fang, Y. (2019). Biomass-derived aviation fuels: Challenges and perspective. Progress in Energy and Combustion Science, 74: 31-49. https://doi.org/10.1016/j.pecs.2019.04.004

[9] Alayi, R., Kasaeian, A., Atabi, F. (2020). Optical modeling and optimization of parabolic trough concentration photovoltaic/thermal system. Environmental Progress \& Sustainable Energy, 39(2): e13303. https://doi.org/10.1002/ep.13303

[10] Zhang, Y.J., Bian, X.J., Tan, W., Song, J. (2017). The indirect energy consumption and $\mathrm{CO}_{2}$ emission caused by household consumption in China: an analysis based on the input-output method. Journal of Cleaner Production, 163: 69-83. https://doi.org/10.1016/j.jclepro.2015.08.044

[11] Arto, I., Capellán-Pérez, I., Lago, R., Bueno, G., Bermejo, R. (2016). The energy requirements of a developed world. Energy for Sustainable Development, 33: 1-13. https://doi.org/10.1016/j.esd.2016.04.001

[12] Altenburg, T., Rodrik, D. (2017). Green industrial policy: Accelerating structural change towards wealthy green economies. Green Industrial Policy.

[13] Kasaeian, A., Shamel, A., Alayi, R. (2015). Simulation and economic optimization of wind turbines and photovoltaic hybrid system with storage battery and hydrogen tank (case study the city of Yazd). Journal of Current Research in Science, 3(5): 105.

[14] Kumar, A., Samadder, S.R. (2017). A review on technological options of waste to energy for effective management of municipal solid waste. Waste Management, 69: 407-422. https://doi.org/10.1016/j.wasman.2017.08.046

[15] Bong, C.P.C., Ho, W.S., Hashim, H., Lim, J.S., Ho, C.S., Tan, W.S.P., Lee, C.T. (2017). Review on the renewable energy and solid waste management policies towards biogas development in Malaysia. Renewable and Sustainable Energy Reviews, 70: 988-998. https://doi.org/10.1016/j.rser.2016.12.004 
[16] Ogunjuyigbe, A.S.O., Ayodele, T.R., Alao, M.A. (2017). Electricity generation from municipal solid waste in some selected cities of Nigeria: An assessment of feasibility, potential and technologies. Renewable and Sustainable Energy Reviews, 80: 149-162. https://doi.org/10.1016/j.rser.2017.05.177

[17] Scarlat, N., Dallemand, J.F., Fahl, F. (2018). Biogas: Developments and perspectives in Europe. Renewable Eenergy, 129: 457-472. https://doi.org/10.1016/j.renene.2018.03.006

[18] Dachs, B., Kinkel, S., Jäger, A., Palčič, I. (2019). Backshoring of production activities in European manufacturing. Journal of Purchasing and Supply Management, 25(3): 100531. https://doi.org/10.1016/j.renene.2018.03.006

[19] dos Santos, R.E., dos Santos, I.F.S., Barros, R.M., Bernal, A.P., Tiago Filho, G.L., da Silva, F.D.G.B. (2019). Generating electrical energy through urban solid waste in Brazil: An economic and energy comparative analysis. Journal of Environmental Management, 231: 198-206. https://doi.org/10.1016/j.jenvman.2018.10.015

[20] Araujo, D.R.R., de Oliveira, J.D., Selva, V.F., Silva, M.M., Santos, S.M. (2017). Generation of domestic waste electrical and electronic equipment on Fernando de Noronha Island: Qualitative and quantitative aspects. Environmental Science and Pollution Research, 24(24): 19703-19713. https://doi.org/10.1007/s11356-0179648-3

[21] Isnam, J.A., Akil, Y.S. (2019). The potential of electrical power generation based on organic waste utilization at Tamangapa landfill Makassar. In Journal of Physics: Conference Series, 1341(5): 052015.

[22] Sjöblom, M., Matsakas, L., Krige, A., Rova, U., Christakopoulos, P. (2017). Direct electricity generation from sweet sorghum stalks and anaerobic sludge. Industrial Crops and Products, 108: 505-511. https://doi.org/10.1016/j.indcrop.2017.06.062

[23] Ayodele, T.R., Alao, M.A., Ogunjuyigbe, A.S.O. (2018). Recyclable resources from municipal solid waste: assessment of its energy, economic and environmental benefits in Nigeria. Resources, Conservation and
Recycling,

134:

165-173.

https://doi.org/10.1016/j.resconrec.2018.03.017

[24] Fernández-Gonzalez, J.M., Grindlay, A.L., SerranoBernardo, F., Rodríguez-Rojas, M.I., Zamorano, M. (2017). Economic and environmental review of Wasteto-Energy systems for municipal solid waste management medium and small municipalities. Waste Management, 67: 360-374. https://doi.org/10.1016/j.wasman.2017.05.003

[25] Singh, A., Basak, P. (2018). Economic and environmental evaluation of municipal solid waste management system using industrial ecology approach: Evidence from India. Journal of Cleaner Production, 195: 10-20. https://doi.org/10.1016/j.jclepro.2018.05.097

[26] Owebor, K., Oko, C.O.C., Diemuodeke, E.O., Ogorure, O.J. (2019). Thermo-environmental and economic analysis of an integrated municipal waste-to-energy solid oxide fuel cell, gas-, steam-, organic fluid-and absorption refrigeration cycle thermal power plants. Applied energy, 239:

https://doi.org/10.1016/j.apenergy.2019.02.032

[27] Saldaña-Durán, C.E., Bernache-Pérez, G., Ojeda-Benitez, S., Cruz-Sotelo, S.E. (2020). Environmental pollution of E-waste: generation, collection, legislation, and recycling practices in Mexico. In Handbook of Electronic Waste Management, 421-442. https://doi.org/10.1016/B978-0-12-817030-4.00021-8

[28] Zhang, Y. (2020). Distributed Renewable Energy in China: Current State and Future Outlook. In: Wang W., Liu Y. (eds) Annual Report on China's Response to Climate Change (2017). Research Series on the Chinese Dream and China's Development Path. Springer, Singapore. https://doi.org/10.1007/978-981-13-9660$1 \_12$

[29] Cudjoe, D., Han, M.S., Nandiwardhana, A.P. (2020). Electricity generation using biogas from organic fraction of municipal solid waste generated in provinces of China: Techno-economic and environmental impact analysis. Fuel Processing Technology, 203: 106381. https://doi.org/10.1016/j.fuproc.2020.106381 